\title{
Large and medium-sized mammals of the Humaitá Forest Reserve, southwestern Amazonia, state of Acre, Brazil
}

\author{
André L. M. Botelho ${ }^{1 *}$, Armando M. Calouro ${ }^{2}$, Luiz H. M. Borges ${ }^{1}$ and Willandia A. Chaves ${ }^{3}$ \\ 1 Universidade Federal do Acre, Programa de Pós-Graduação em Ecologia e Manejo dos Recursos Naturais. Rodovia BR 364, Km 04, no 6637 - \\ Distrito Industrial. CEP:69915-900. Rio Branco, AC, Brazil. \\ 2 Universidade Federal do Acre, Centro de Ciências Biológicas e da Natureza.Rodovia BR 364, Km 04, no 6637 - Distrito Industrial. CEP 69915 -900. \\ Rio Branco, AC, Brazil. \\ 3 Instituto Piagaçu. Rua UZ quadra Z, no 8 - Conjunto Morada do Sol Aleixo. CEP 69060-095. Manaus, AM, Brazil. \\ * Corresponding author. E-mail: botelho.alm@gmail.com
}

\begin{abstract}
Large and medium-sized mammals are essential to forest ecosystems as they are responsible for prey population control, seed dispersal and predation. A mammal survey was conducted in the Humaitá Forest Reserve (HFR), a $20 \mathrm{~km}^{2}$ forest fragment located in the southeastern part of the state. The survey was carried out using census transects, camera traps, and occasional records such as bones and footprints. In all, 27 species of large to medium-sized mammals were recorded for the RFH, representing $48 \%$ of those expected for the region. Dasyprocta fuliginosa, Pecari tajacu and Didelphis marsupialis were the species with the highest number of records with camera traps. The occurrence of two species of cats (Leopardus pardalis and Puma concolor) and three endangered species (Callimico goeldii, Myrmecophaga tridactyla and Priodontes maximus) are important records for the RFH. The results may aid future research on the ecology, biogeography and conservation of mammals in the region.
\end{abstract}

\section{INTRODUCTION}

Large and medium-sized mammals (weight $>1 \mathrm{~kg}$, primates and members of the family Sciuridae) play a fundamental role in the functioning of Amazonian ecosystems, such as prey population control and dispersion/predation of seeds. Moreover, they are an important source of protein and fat for human populations who live outside urban centers (Redford and Robinson 1987; Dirzo and Mendoza 2007; Stoner et al. 2007; Estes et al. 2011). Despite their great ecological importance, large and medium-sized mammals have been poorly studied in the state of Acre, and the available works focused on rapid surveys (e.g. Calouro 1999), assessments of the effects of subsistence hunting on mammals (e.g. Calouro and Marinho-Filho 2005; Rosas and Drumond 2007), and studies of primate autoecology (e.g. Bicca-Marques and Garber 2003; Rehg 2006).

Acre is a state of extreme importance for the conservation of mammals because $86.87 \%$ of its area is still covered by forests (INPE 2010). The state has an estimated mammal richness of 203 species (SEMA 2010), representing 29\% of the total of Brazilian mammals (Paglia et al. 2012), and more than half of its territory is considered an area of "extreme" and "very high" biological importance for biodiversity conservation (Souza et al. 2003).

Although Acre is among the Amazonian states that maintains most of its original vegetation cover, the eastern region of the state has been extensively deforested and its forests fragmented. Habitat destruction and hunting are the main threats to large and medium-sized mammals, causing significant changes in the richness and abundance of species living in fragmented environments (Chiarello 1999; Peres 2001; Rosser and Mainka 2002). However, fragmented environments are seen as key elements for the recovery of landscapes, since they harbor most of the native biodiversity of the region (Viana and Pinheiro 1998), making the retention of certain species viable, which is more than that observed in completely deforested areas (Turner and Corlett 1996).

Thus, knowledge of the local fauna is the first step to enable future conservation policies, and provide basic information for more complex ecological and biogeographical studies. Thus, the aim of this study was to produce an inventory of the species of large and mediumsized mammals at Humaitá Forest Reserve, and to estimate their relative abundance using camera traps.

\section{Materials ANd Methods}

Study Area

The Humaitá Forest Reserve (HFR) has a total area of approximately $20 \mathrm{~km}^{2}$, with altitudes ranging from 130 $\mathrm{m}$ to $179 \mathrm{~m}$. The HFR belongs to the Universidade Federal do Acre (UFAC) and is located in the municipality of Porto

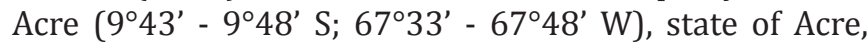
northwestern Brazil. The HFR has a rectangular shapen (in its lateral limits, when viewed from above) and has two parallel tracks, approximately $12 \mathrm{~km}$ in length, which are about 2,000 $\mathrm{m}$ apart. The area is surrounded by the Humaitá Settlement Project as well as small farms. The Acre River limits the eastern border of the HFR (Figure 1). The climate is classified as Am (Köppen), and has an average rainfall of $1,944 \mathrm{~mm}$ and a mean temperature of $26^{\circ} \mathrm{C}$ (Duarte 2005).

The vegetation of the HFR has a clear structural difference with regard to the dominance of the arboreal component, suggesting a vegetation gradient along the toposequence plateau, the slope and the lowland. On the plateau the dominant vegetal formation is open forest with bamboo (Guadua weberbaueri) while on the lowland 
there is a dominance of open forest with palms (Barroso et al. 2011).

\section{Data Collection}

The survey of mammals of the HFR was carried out using two sampling methods at different times: observation trails in the years 1999 and 2000, and camera trapping during 2009 and 2010. Observations were made along $5 \mathrm{~km}$ of track trails marked on the edges of the reserve. During observations, the time, date, and number of species and individuals sighted were recorded. Fieldwork was performed in the morning, usually starting at 6 am and ending at mid-day (NRC 1981; Peres 1999). In all, $220 \mathrm{~km}$ were traveled in the months of October, November and December 1999 and May and June 2000.

Camera traps were also placed on the tracks bordering the HFR and, because they are old tracks (built over 20 years ago), the number of catches was maximized (Karanth and Nichols 1998). We used six camera traps TIGRINUS ANALOG 6.0 tied on trees at a height of $30 \mathrm{~cm}$ from the soil, and the locality was baited with sardines in oil and slices of bacon. The traps operated 24 hours per day, with the interval between two photographs set at $30 \mathrm{~s}$. Sampling points were set up for 15 to 30 days, at a distance of $500 \mathrm{~m}$ to $1,000 \mathrm{~m}$ from one another. During the rainy season (December to March) sampling was concentrated on the western portion of the fragment, since movement throughout most of the area was prevented by flooded streams.

The total collection effort was calculated by multiplying the number of cameras used by the number of days that those were functioning, obtaining the result in trap-nights. Thus from October 2009 to August 2010 the total effort was 850 trap-nights.

During fieldwork with the camera traps, occasional records such as sightings, trails and collection of hair and bones (materials in good condition were deposited in the Zoological Collection of Mammals - CZM UFAC) were used to complement the list of large and medium-sized

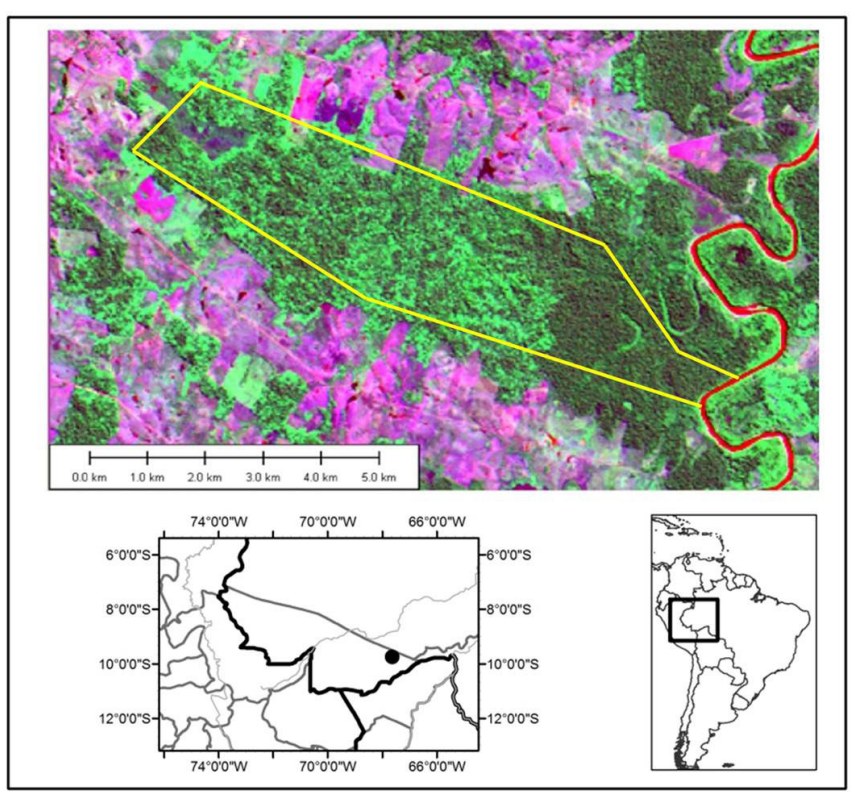

Figure 1. Location ofthe Humaitá Forest Reserve (HFR), municipality of Porto Acre, Acre, Braziland Acre River (in red). (Landsat image granted by FUNTAC/2008). mammals of the fragment. The taxonomic nomenclature follows the recent list of mammals of Brazil published by Paglia et al. (2012).

\section{RESULTS AND DISCUSSION}

In 1999 and 2000, 15 species of large and mediumsized mammals were recorded along the observation trails. In 2009 and 2010 twenty-one species were recorded, ten of which with camera traps. Therefore, between the two phases of data collection, 27 species of large and mediumsized mammals were recorded in the HFR (Table 1).

of the few mammal inventories carried out in the state of Acre, the one performed by Calouro (1999) is noteworthy. During a rapid ecological assessment the author recorded 43 species of large and medium-sized mammals in the Serra do Divisor National Park $(600 \mathrm{~km}$ away from HFR), one of the protected areas with greatest species richness of large and medium-sized mammals in the Neotropics.

Surveys of mammals using camera traps are still rare in the Amazon basin (Trolle 2003; Martins et al. 2007; Tobler et al. 2008; Negrões et al. 2011). Trolle (2003) recorded 13 species of mammals with six camera traps in his study in the Xixuaú Nature Reserve in the state of Roraima, Brazil. Tobler et al. (2008), with a total effort of 2,340 trap-nights, recorded 27 species of mammals with camera traps in the Peruvian Amazon and demonstrated the efficiency of the use of camera traps for large and medium-sized mammal inventories. The large number of species recorded by Tobler et al. (2008), compared to that found in the HFR in the present study, is probably due to the greater sampling effort and to the fact that the study was conducted in a continuous area $\left(1,400 \mathrm{~km}^{2}\right)$, not in a forest fragment as in the HFR, since the larger the area, the more species are expected to occur on the site (MacArthur and Wilson 1967).

For the region where the HFR is located, 56 species of large and medium-sized mammals are expected to occur, according to the geographical distribution described in Rowe (1996), Emmons and Feer (1997), Eisenberg and Redford (1999), Gardner (2007) and Wilson and Mittermeier (2009). Thus, the 27 species recorded in the present study represent only $48.2 \%$ of the species that possibly occur in the area. When only the species recorded with the camera traps were analyzed, it was noted that $27.7 \%$ of the 36 species of terrestrial or arboreal-terrestrial mammals expected for the region were recorded. Thus, it is possible that with more effort using camera traps, new species might be recorded in the area. However, some species that are relatively easy to record, such as Tapirus terrestris (Linnaeus, 1758) and Tayassu pecari (Link, 1795), seem to have become extinct in the area probably as a result of hunting pressure that occurs in the region (Cullen et al. 2000; Michalski and Peres 2007; Salvador et al. 2010). Although not confirmed by interviews with residents, hunting pressure at the HFR is evident, as during the study several hunting dogs were recorded on the camera traps and some used shotgun shells were also found.

The primates with highest relative abundance (number of groups/10 km traveled) recorded in the 1999 and 2000 censuses were Saguinus weddelli and Callicebus cupreus. 
The lowest relative abundance of primates recorded in the HFR was of Aloutta puruensis (Table 2). The Purús Red Howler Monkey was recorded only once during the surveys in 1999 and 2000, and during activities with camera traps the species was not seen and there was no record of vocalization. This may suggest a possible population depletion or even a local extinction of the species in the area, since large primates are particularly sensitive to habitat fragmentation and hunting pressure on Amazon (Peres 1997; Peres 2001; Michalski and Peres 2005). New sampling visualization tracks and interviews with people living around the reserve can confirm the hypothesis of the disappearance of the species in the area.

The relative abundance of mammals recorded by camera traps is shown in Table 2. The species with the largest number of records were Dasyprocta fuliginosa, Pecari tajacu and Didelphis marsupialis (Figure 2).

Studies that calculate relative abundance in the Amazon are still scarce (Martins et al. 2007; Tobler et al. 2008; Negrões et al. 2011). A comparison between our study and the study of Tobler et al. (2008), in southeastern Peru (table 2), shows three species (Cuniculus paca, Dasyprocta fuliginosa and Leopardus pardalis) with relative abundance noticeably superior to that found in HFR. Despite the fact that these significant differences may be due to fragmentation and hunting effects in the HFR (Chiarello 1999; Cullen et al. 2000; Cullen et al. 2001; Peres 2001), extrapolations from studies that are based on the relative abundance obtained from camera traps are not recommended because of the lack of standardization

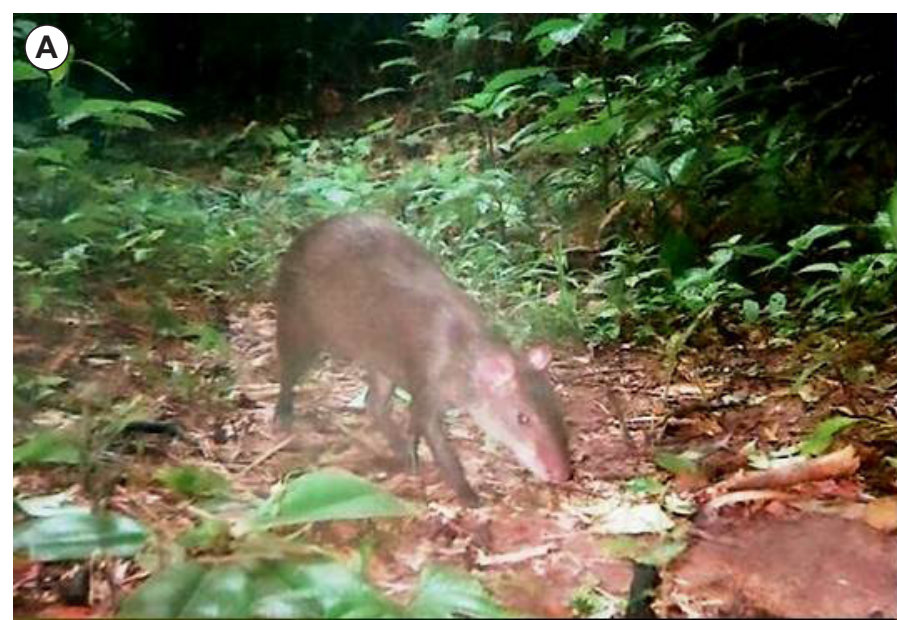

B C

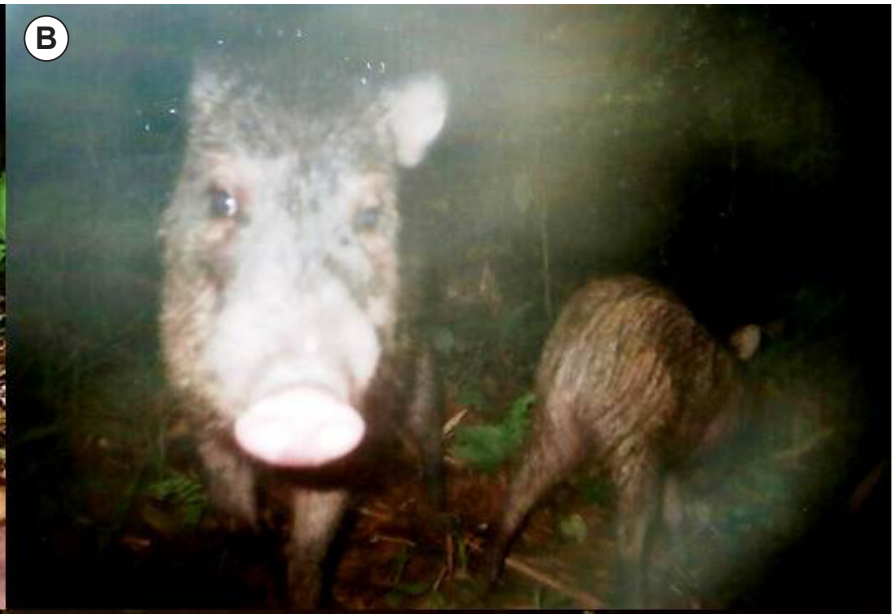

(D)
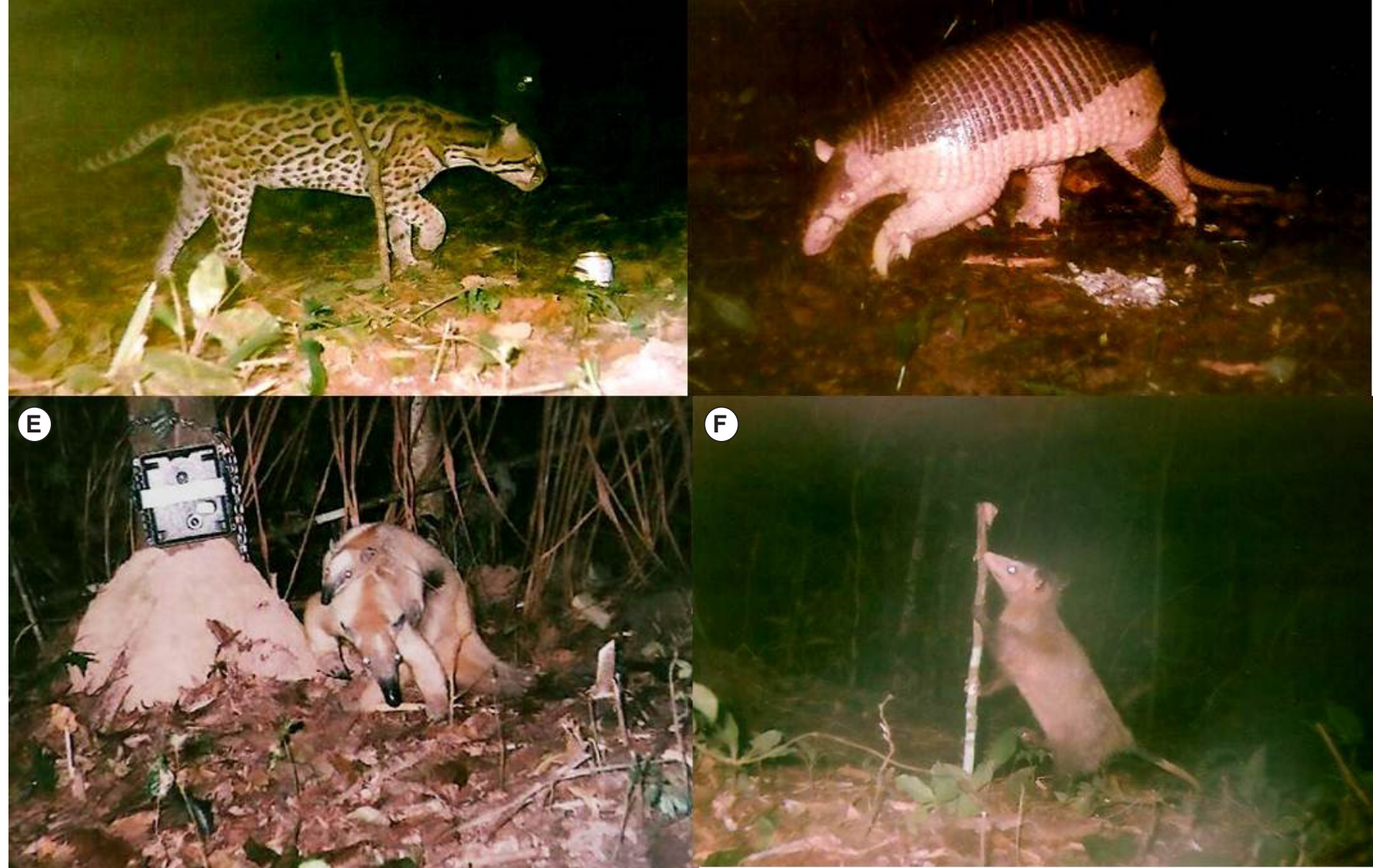

FIGURE 2. Some mammals at the Humaitá Forest Reserve (HFR) that were photographed using camera traps. A: Dasyprocta fuliginosa. B: Pecari tajacu. C: Leopardus pardalis. D: Priodontes maximus. E: Tamandua tetradactyla. F: Didelphis marsupialis. 
of such methods (Kasper et al. 2007; 0'Brien 2010).

We recorded five species of carnivores in the HFR, Leopardus pardalis and Eira barbara being the ones that were recorded with the camera traps. The ocelot is a meso- predator, directly influencing the diversity of its prey (Fonseca and Robinson 1990), as well as influencing the abundance of other medium-sized felines (Oliveira et al. 2010). In the IUCN (International Union for Conservation

TABLE 1. Species of large and medium-sized mammals recorded for the Humaitá Forest Reserve (Acre, Brazil) and types of records: photographic record (P), trail visualization (V), bones (B) and footprints (F). IUCN categories: Data Deficient (DD) Least Concern (LC), Vulnerable (VU).

\begin{tabular}{|c|c|c|c|c|}
\hline TAXON & COMMON NAME & PERIOD OF RECORD & TYPE OF RECORD & IUCN STATUS \\
\hline \multicolumn{5}{|l|}{ ARTIODACTYLA } \\
\hline \multicolumn{5}{|l|}{ Cervidae } \\
\hline Mazama americana (Erxleben, 1777) & Red brocket deer & $2009-2010$ & F; B & DD \\
\hline Pecari tajacu(Linnaeus, 1758) & Collared peccary & 1999-2000; 2009-2010 & P; B; V & LC \\
\hline \multicolumn{5}{|l|}{ CARNIVORA } \\
\hline \multicolumn{5}{|l|}{ FELIDAE } \\
\hline Puma concolor (Linnaeus, 1771) & Cougar & $2009-2010$ & $\mathbf{V}$ & LC \\
\hline \multicolumn{5}{|l|}{ MUSTELIDAE } \\
\hline Eira barbara (Linnaeus, 1758) & Tayra & $1999-2000 ; 2009-2010$ & V; P & LC \\
\hline \multicolumn{5}{|l|}{ PROCYONIDAE } \\
\hline Nasua nasua (Linnaeus, 1766) & Coati & $1999-2000 ; 2009-2010$ & $\mathbf{V}$ & LC \\
\hline Potos flavus (Schreber, 1774) & Kinkajou & $1999-2000$ & $\mathbf{V}$ & LC \\
\hline \multicolumn{5}{|l|}{ DASYPODIDAE } \\
\hline Dasypus novemcinctus Linnaeus, 1758 & Nine-banded armadillo & $2009-2010$ & $P ; F$ & LC \\
\hline Priodontes maximus (Kerr, 1792) & Giant armadillo & $2009-2010$ & $\mathbf{P}$ & VU \\
\hline \multicolumn{5}{|l|}{ DIDELPHIMORPHIA } \\
\hline \multicolumn{5}{|l|}{ DIDELPHIDAE } \\
\hline Didelphis marsupialis Linnaeus, 1758 & Black-eared opossum & $2009-2010$ & $\mathbf{P}$ & LC \\
\hline \multicolumn{5}{|l|}{ PILOSA } \\
\hline \multicolumn{5}{|l|}{ MEGALONYCHIDAE } \\
\hline Choloepus sp. Illiger, 1811. & Two-toed sloth & $2009-2010$ & $\mathbf{B}^{*}$ & LC \\
\hline \multicolumn{5}{|l|}{ MYRMECOPHAGIDAE } \\
\hline Myrmecophaga tridactyla Linnaeus, 1758 & Giant anteater & $2009-2010$ & $\mathbf{V}$ & VU \\
\hline Tamandua tetradactyla (Linnaeus, 1758) & Lesser anteater & $2009-2010$ & $\mathbf{P}$ & LC \\
\hline \multicolumn{5}{|l|}{ PRIMATES } \\
\hline \multicolumn{5}{|l|}{ CALlitrichidae } \\
\hline Callimico goeldii (Thomas, 1904) & Goeldi’s Monkey & $1999-2000$ & $\mathbf{V}$ & VU \\
\hline Saguinus weddelli weddelli (Deville, 1849) & Saddle-back tamarin & $1999-2000 ; 2009-2010$ & $\mathbf{V}$ & LC \\
\hline Saguinus imperator imperator (Goeldi, 1907) & Emperor tamarin & $1999-2000 ; 2009-2010$ & $\mathbf{V}$ & LC \\
\hline \multicolumn{5}{|l|}{ CEBIDAE } \\
\hline Cebus unicolor Spix, 1823 & $\begin{array}{l}\text { Spix's White-fronted } \\
\text { Capuchin }\end{array}$ & $1999-2000$ & $\mathbf{V}$ & LC \\
\hline Saimiri boliviensis (I. Geoffroy and de Blainville, 1834) & Bolivian squirrel monkey & $1999-2000 ; 2009-2010$ & $\mathbf{V}$ & LC \\
\hline Sapajus macrocephalus (Spix, 1823) & Large-headed Capuchin & $1999-2000$ & $\mathbf{V}$ & LC \\
\hline \multicolumn{5}{|l|}{ Pitheciidae } \\
\hline Callicebus cupreus (Spix,1823) & Red titi monkey & $1999-2000 ; 2009-2010$ & $\mathbf{V}$ & LC \\
\hline Pithecia irrorata Gray, 1842 & Gray's Bald-faced Saki & $1999-2000$ & $\mathbf{V}$ & LC \\
\hline \multicolumn{5}{|l|}{ RODENTIA } \\
\hline \multicolumn{5}{|l|}{ CAVIIDAE } \\
\hline Hydrochoerus hydrochaeris (Linnaeus, 1766) & Capybara & $2009-2010$ & $\mathbf{P}$ & $\mathbf{L C}$ \\
\hline \multicolumn{5}{|l|}{ Cuniculidae } \\
\hline Cuniculus paca (Linnaeus, 1766) & Spotted paca & $2009-2010$ & $\mathbf{P}$ & LC \\
\hline DASYPROCTIDAE & & & & \\
\hline Dasyprocta fuliginosa Wagler, 1832 & Black agouti & $1999-2000 ; 2009-2010$ & P; V & LC \\
\hline ERITHIZONTIDAE & & & & \\
\hline Coendou prehensilis (Linnaeus, 1758) & Brazilian Porcupine & $1999-2000 ; 2009-2010$ & B & LC \\
\hline SCIURIDAE & & & & \\
\hline Urosciurus cf. spadiceus Olfers, 1818 & $\begin{array}{l}\text { Southern Amazon red } \\
\text { squirrel }\end{array}$ & $1999-2000 ; 2009-2010$ & $\mathbf{V}$ & LC \\
\hline
\end{tabular}

*UFAC-CZM 680. 
of Nature) red list, the species is listed as of least concern (IUCN 2012). In the Red Book of Brazilian Endangered Animals, only a subspecies of ocelot (L. p. mitis), that does not occurs in the state of Acre, is considered threatened (Chiarello et al. 2008).

Another cat recorded in the area was Puma concolor. This species was observed only once during the study period. Despite its wide geographic distribution, populations of $P$. concolor from northeastern, southern and southeastern Brazil are threatened with extinction (Chiarello et al. 2008) The presence of the puma is important for the HFR as it is a key species for maintaining ecosystems and being threatened by habitat destruction (Terborgh et al. 2001; Sana and Cullen 2008). Despite the ecological value of the puma, records of these species in the area cause concern due to possible problems between man and predator, since conflicts between large cats and ranchers near forest fragments are recurrent (Michalski et al. 2006; Palmeira and Barrella 2007; Oliveira et al. 2012).

The record of Priodontes maximus may have been facilitated by the existence of food taboos amongst hunters in the state of Acre. The food taboo refers to beliefs in some cultures, in which some animals are discarded because of food preferences or cultural beliefs (Ross 1978). The giant armadillo (Figure 2) is hunted outside the state of Acre (Peres 2000), but in this region there is a food taboo that states that if a person kills a giant armadillo someone in their family will die (Calouro and Marinho-Filho 2005). Thus, these forms of food taboos and beliefs may be helping to conserve this species in the fragment and the state.

TABLE 2. Relative abundance of primates groups in the RFH.

\begin{tabular}{lc}
\hline SPECIES & GROUPS/10 KM TRAVELED \\
\hline Alouatta puruensis & 0.04 \\
Callicebus cupreus & 0.64 \\
Callimico goeldii & 0.09 \\
Cebus unicolor & 0.32 \\
Sapajus macrocephalus & 0.27 \\
Pithecia irrorata & 0.36 \\
Saguinus weddelli & 0.82 \\
Saguinus imperator & 0.36 \\
Saimiri boliviensis & 0.41 \\
\hline
\end{tabular}

TABLE 3. Species recorded with camera traps in the Humaitá Forest Reserve (Acre, Brazil) and respective relative abundance ${ }^{1}$.

\begin{tabular}{|c|c|c|c|}
\hline \multirow[b]{2}{*}{ SPECIES } & \multirow{2}{*}{$\begin{array}{c}\text { N. OF } \\
\text { RECORDS } \\
\text { AT HFR }\end{array}$} & \multicolumn{2}{|c|}{ RELATIVE ABUINDANCE $^{1}$} \\
\hline & & HFR & $\begin{array}{c}\text { SOUTHEASTERN } \\
\text { PERU }^{2}\end{array}$ \\
\hline Cuniculus paca & 3 & 3.5 & 14.1 \\
\hline Dasyprocta fuliginosa & 10 & 11.8 & $20.5^{*}$ \\
\hline Hydrochoerus hydrochaeris & 1 & 1.2 & - \\
\hline Tamandua tetradactyla & 1 & 1.2 & 0.9 \\
\hline Dasypus novemcinctus & 1 & 1.2 & 0.9 \\
\hline Priodontes maximus & 2 & 2.4 & 3 \\
\hline Leopardus pardalis & 3 & 3.5 & 13.2 \\
\hline Eira barbara & 1 & 1.2 & 3.4 \\
\hline Pecari tajacu & 3 & 3.5 & 8.1 \\
\hline Didelphis marsupialis & 7 & 8.2 & 6.8 \\
\hline
\end{tabular}

${ }^{1}$ Number of records/ camera trap-nights x $1000{ }^{2}$ Tobler et al. 2008. * Individuals of the same genus.
The list of species presented here contributes significantly to the knowledge of the fauna of the HFR. Studies such as this are important to guide future work on ecology and biogeography of the species recorded herein especially those threatened with extinction. Therefore, the preliminary knowledge of large and medium-sized mammals featured in this article will serve as a starting point for the development of ecological research to investigate the effects that habitat fragmentation and poaching have on the community of mammals in the region of the Humaitá Settlement Project.

Acknowledgments: We thank the Fundação de Tecnologia do Estado do Acre - FUNTAC, the Conselho Nacional de Desenvolvimento Científico e Tecnológico - CNPq, and the Superintendência da Zona Franca de Manaus - SUFRAMA for funding the project and for logistical support in field activities. We also thank Nathocley Mendes Venâncio for his help in Figure 1 and Richarlly da Costa Silva for his support in field activities.

\section{Literature Cited}

Barroso, J.G., C.I. Salimon, M. Silveira and E.F. Morato. 2011. Influência de fatores ambientais sobre a ocorrência e distribuição espacial de cinco espécies madeireiras exploradas no Estado do Acre, Brasil. ScientiaForestalis 39(92): 489-499.

Bicca-Marques, J.C. and P.A. Garber. 2003. Experimental field study of the relative costs and benefits to wild tamarins (Saguinus imperator and S. fuscicollis) of exploiting contestable food patches as single- and mixed-species troops. American Journal of Primatology 60: 139-153.

Calouro, A.M. 1999. Riqueza de mamíferos de grande e médio porte do Parque Nacional da Serra do Divisor (Acre, Brasil). Revista Brasileira de Zoologia 16(2): 195-213.

Calouro, A.M. and J.S. Marinho-Filho. 2005. A caça e a pesca de subsistência entre seringueiros ribeirinhos e não-ribeirinhos da Floresta Estadual do Antimary (AC); p.109-135 In P. Drumond (ed.). Fauna do Acre. Rio Branco: EDUFAC.

Chiarello, A.G. 1999. Effects of fragmentation of the Atlantic forest on mammal communities in southeastern Brazil. Biological Conservation 89: 71-82.

Chiarello, A.G., L.M.S. Aguiar, R. Cerqeira, F.R. Melo and V.M.F. Silva, 2008. Mamíferos ameaçados de extinção no Brasil; p. 680-883 In: A.B.M. Machado, G.C. Drummond and A.P Paglia (ed.). Livro vermelho da fauna brasileira ameaçada de extinção. Volume II. Brasília: Fundação Biodiversitas.

Cullen JR, L., R.E. Bodmer and C. Valladares-Pádua. 2000. Effects of hunting in habitat fragments of the Atlantic forests, Brazil. Biological Conservation 95: 49-56.

Cullen JR, L., R.E. Bodmer and C. Valladares-Pádua. 2001. Ecological consequences of hunting in Atlantic forest patches, São Paulo, Brazil. Oryx 35(2): 137-144.

Dirzo, R. and E. Mendoza. 2007. Size-related differential seed predation in a heavily defaunated neotropical rain forest. Biotropica 39(3): 355362.

Duarte, A.F. 2005. Variabilidade e tendência das chuvas em Rio Branco, Acre, Brasil. Revista Brasileira de Meteorologia 20(1): 37-42.

Eisenberg, J.F. and K.H. Redford. 1999. Mammals of the neotropics: Volume III: Ecuador, Peru, Bolivia, Brazil. Chicago: University of Chicago Press. $624 \mathrm{p}$.

Emmons, L.H. and F. Feer. 1997. Neotropical rainforest mammals: a field guide. Chicago: The University of Chicago Press. 307 p.

Estes, J.A., J. Terborgh, J.S. Brashares, M.E. Power, J. Berger, W.J. Bond, S.R. Carpenter, T.E. Essington, R.D. Holt, J.B.C. Jackson, R.J. Marquis, L. Oksanen, T. Oksanen, R.T. Paine, E.K. Pikitch, W.J. Ripple, S.A. Sandin, M. Scheffer, T.W. Schoener, J.B. Shurin, A.R.E. Sinclair, M.E. Soulé, R. Virtanen and D.A. Wardle. 2011. Trophic downgrading of Planet Earth. Science 333: 301-306.

Fonseca, G.A.B. and J.G. Robinson. 1990. Forest size and structure: Competitive and predatory effects on small mammal communities. Biological Conservation 53: 265-264.

Gardner, A.L. 2007. Mammals of South America Volume 1, Marsupials, xenarthrans, shrews and bats. Chicago: The University of Chicago Press. 669 p.

INPE 2010. Estimativas anuais das taxas de desmatamento na Amazônia geradas pelo relatório do projeto PRODES. Electronic Database accessible at http://www.obt.inpe.br/prodes/prodes_1988_2009. htm. Captured on 25 November 2010.

IUCN 2012. IUCN Red List of Threatened Species. Version 2011.2. Electronic Database accessible at http://www.iucnredlist.org/. Captured on 10 February 2012. 
Karanth, K.U. and J.D. Nichols. 1998. Estimation of tiger densities in India using photographic captures and recaptures. Ecology 79(8): 28562862.

Kasper C.B., F.D. Mazim, J.B.G. Soares, T.G. Oliveira and M.E. Fabián. 2007. Composição e abundância relativa dos mamíferos de médio e grande porte no Parque Estadual do Turvo, Rio Grande do Sul, Brasil. Revista Brasileira de Zoologia 24(4): 1087-1100.

MacArthur, R.H. and E.O. Wilson. 1967. The theory of island biogeography. Princeton: Princeton University Press. 224 p.

Martins, S.S., J.G. Sanderson and J.S. Silva-Júnior. 2007. Monitoring mammals in the Caxiuanã National Forest, Brazil - First results from the Tropical Ecology, Assessment and Monitoring (TEAM) program. Biodiversity and Conservation 16: 857-870.

Michalski, F., R.L.P Boulhosa, A. Faria and C.A. Peres. 2006. Human-wildlife conflicts in a fragmented Amazonian forest landscape: determinants of large felid depredation on livestock. Animal Conservation 9: 179188.

Michalski, F. and C.A. Peres. 2005. Anthropogenic determinants of primate and carnivore local extinctions in a fragmented forest landscape of southern Amazonia. Biological Conservation 124: 383-396.

Michalski, F. and C.A. Peres. 2007. Disturbance-mediated mammal persistence and abundance-area relationships in Amazonian forest fragments. Conservation Biology 21(6): 1626-1640.

National Research Council (NRC). 1981. Techniques for the study of primate population ecology. Washington, DC: National Academic Press. 233 p.

Negrões, N., E. Revilla, C. Fonseca, A.M.V.M. Soares, A.T.A. Jácomo and L. Silveira. 2011. Private forest reserves can aid in preserving the community of medium and large-sized vertebrates in the Amazon arc of deforestation. Biodiversity and Conservation 20: 505-518.

O’Brien, T.G. 2011. Abundance, density and relative abundance: A conceptual framework; p. 71-96 In A.F. O'Connell, J.D. Nichols and K.U. Karanth (ed.). Camera traps in animal ecology methods and analyses. Tokio: Springer.

Oliveira, T.G., E.E. Ramalho and R.C. Paula. 2012. Red list assessment of the jaguar in Brazilian Amazonia. Cat News 7: 8-13.

Oliveira, T.G., M.A. Tortato, L. Silveira, C.B. Kasper, F.D. Mazim, M. Lucherini, A.T. Jácomo, J.B.G. Soares, R.V. Marques and M. Sunquist. 2010. Ocelot ecology and its effect on the small-felid guild in the lowland neotropics; p. 563-584 In D.W. Macdonald and A.J. Loveridge (ed.). Biology and conservation of wild felids. Oxford: Oxford University Press.

Paglia, A.P., G.A.B Fonseca, A.B. Rylands, G. Herrmann, L.M.S. Aguiar, A.G. Chiarello, Y.L.R. Leite, L.P. Costa, S. Siciliano, M.C.M. Kierulff, S.L. Mendes, V.C. Tavares, R.A. Mittermeier and J.L. Patton. 2012. Lista Anotada dos Mamíferos do Brasil / Annotated Checklist of Brazilian Mammals. 2a Edição / 2nd Edition. Occasional Papers in Conservation Biology (6). Arlington, VA: Conservation International. 76 p.

Palmeira, F.B.L. and W. Barrela, 2007. Conflitos causados pela predação de rebanhos domésticos por grandes felinos em comunidades quilombolas na Mata Atlântica. Biota Neotropica 7(1): 119-128.

Peres, C.A. 1997. Effects of habitat quality and hunting pressure on arboreal folivore densities in Neotropical Forests: A case study of howler monkeys (Alouatta spp.). Folia Primatologica 68: 199-222.

Peres, C.A. 1999. General guidelines for standardizing line-transect surveys of tropical forest primates. Neotropical Primates 7(1): 11-16.

Peres, C.A. 2000. Effects of subsistence hunting on vertebrate community structure in Amazonian forests. Conservation Biology 14(1): 240-253.
Peres, C.A. 2001. Synergistic effects of subsistence hunting and habitat fragmentation on Amazonian forest vertebrates. Conservation Biology 15(6): 1490-1504.

Redford, K.H. and J.G. Robinson. 1987. The game of choice: patterns of indian and colonist hunting in the neotropics. American Anthropologist 89: 650-667.

Rehg, J.A. 2006. Seasonal variation in polyspecific associations among Callimico goeldii, Saguinus labiatus and Saguinus fuscicollis in Acre, Brazil. International Journal of Primatology 27(5): 1399-1428.

Rosas, G.K.C. and P.M. Drumond. 2007. Caracterização da caça de subsistência em dois seringais localizados no Estado do Acre, Amazônia. EMBRAPA Documentos (109): 1-31.

Ross, E.B. 1978. Food taboos, diet, and hunting strategy: the adaptation to animals in Amazon cultural ecology. Current Anthropology 19(1): 1-36.

Rosser, A.M. and S.A. Mainka. 2002. Overexploitation and species extinctions. Conservation Biology 16(3): 584-586.

Rowe, N. 1996. The pictorial guide to living primates. East Hampton: Pogonia Press. 263 p.

Salvador, S., M. Claveroa and R.L. Pitman. 2011. Large mammal species richness and habitat use in an upper Amazonian forest used for ecotourism. Mammalian Biology 76: 115-123.

Sana, D.A. and L. Cullen Jr. 2008. Puma concolor capricornensis; p.795799 In A.B.M. Machado, G.C. Drummond and A.P Paglia (ed.). Livro vermelho da fauna brasileira ameaçada de extinção. Brasília: Fundação Biodiversitas.

Secretaria de Estado de Meio Ambiente (SEMA). 2010. Coleção Temática do ZEE v. 3 Recursos naturais: biodiversidade e ambientes do Acre. Rio Branco: SEMA Acre. 130 p.

Souza, M.B., M. Silveira, M.R.M. Lopes, L.J.S. Vieira, E. Guilherme, A.M. Calouro and E.F. Morato. 2003. A biodiversidade no estado do Acre: conhecimento atual, conservação e perspectivas. T\&C Amazônia 1(3): 45-56.

Stoner, K.E., K. Vulinec, S.J. Wright and C.A. Peres. 2007. Hunting and plant community dynamics in tropical forest: a synthesis and future directions. Biotropica 39(3): 385-392.

Terborgh, J., L. Lopez, P.V. Nuñez, M. Rao, G. Shahabuddin, G. Orihuela, M. Riveros, M.R. Ascanio, G.H. Adler, T.D. Lambert and L. Balbas. 2001. Ecological meltdown in predator-free forest fragments. Science 294: 1923-1926.

Tobler, M.W., S.E. Carrillo-Percastegui, R.L. Pitman, R. Mares and G. Powell. 2008. An evaluation of camera traps for inventorying large and medium-sized terrestrial rainforest mammals. Animal Conservation 11: 169-178.

Trolle, M. 2003. Mammal survey in the Rio Jauaperí region, Rio Negro Basin, the Amazon, Brazil. Mammalia 67(1): 75-83.

Turner, I.M. and R.T. Corlett. 1996. The conservation value of small, isolated fragments of lowland tropical rain forest. Trends in Ecology and Evolution 11(8): 330-333.

Viana, V.M. and L.A.F.V. Pinheiro. 1998. Conservação da biodiversidade em fragmentos. Série Técnica Ipef 12(32): 25-42.

Wilson, D.E. and R.A. Mittermeier. 2009. Handbook of the mammals of the world. 1. Carnivores. Barcelona: Lynx Edicions. 727 p.

RECEIVED: July 2012

ACCEPTED: October 2012

Published ONLINE: December 2012

EDITORIAL RESPONSIBILITY: Fabio Oliveira do Nascimento 